\title{
A Digital Quandary: Limited vs. Broadly Accessible Collections
}

\author{
Andrea Jackson \& Christine Wiseman
}

Atlanta University Center Robert W. Woodruff Library

Oberlin Digital Scholarship Conference

June 11, 2016 


\section{AUC Woodruff Library}

The AUC Woodruff Library serves as the center of the academic village for Clark Atlanta University, the Interdenominational Theological Center, Morehouse College and Spelman College, providing the highest level of information resources and services in support of teaching learning, scholarship, and cultural preservation of the Atlanta University Center.

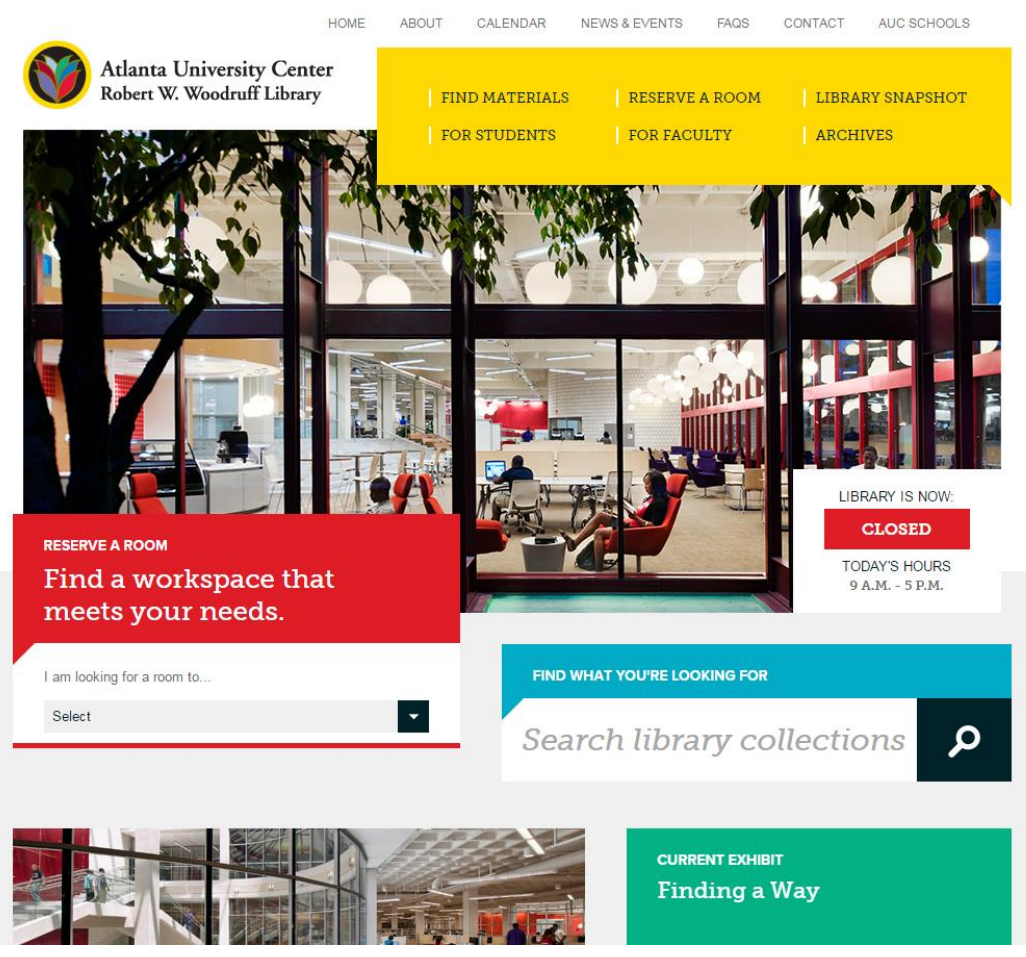




\section{Archives Research Center}

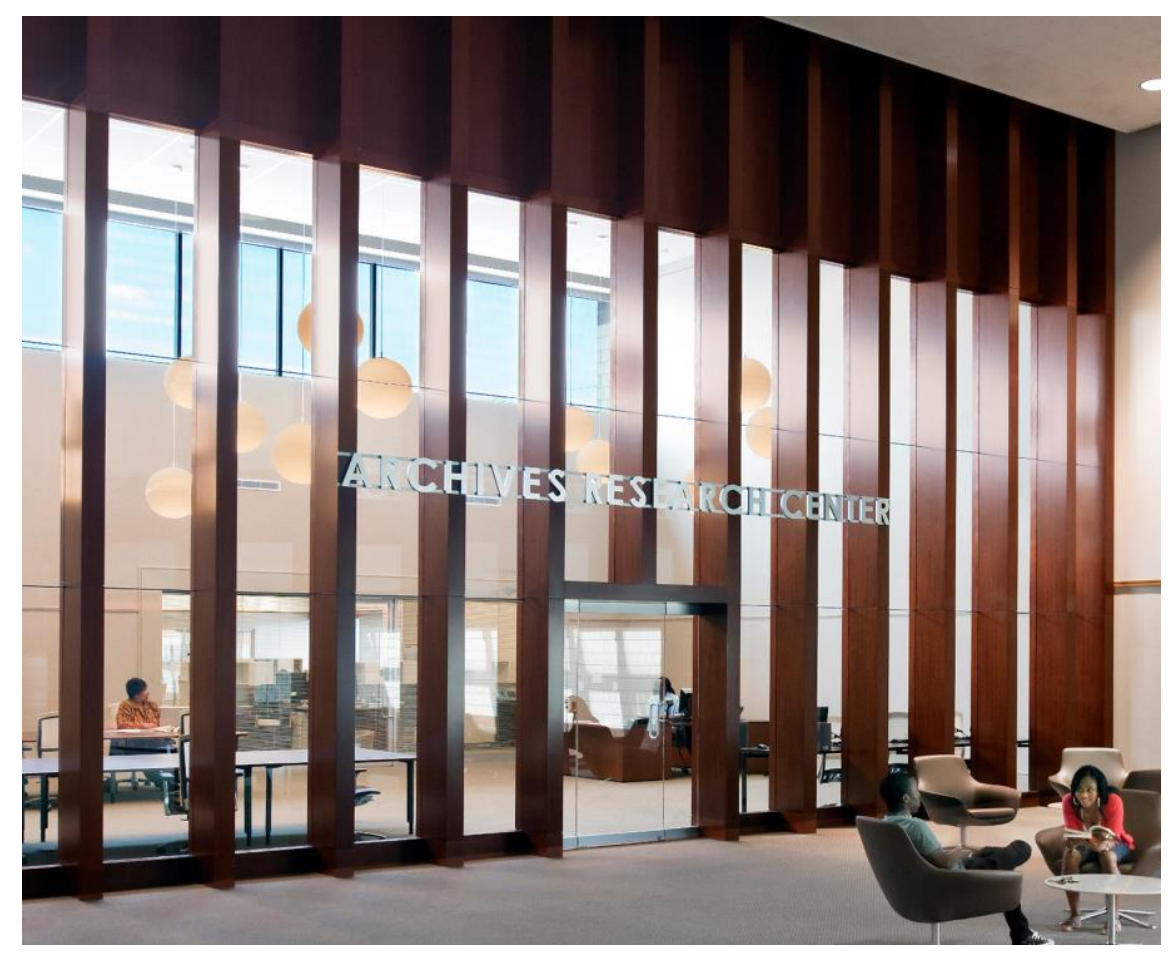

- "Premier Destination Archives"

ARC is a cultural asset and active participant in teaching and scholarship, providing collaborative leadership in the preservation, access, and collection development of archival resources.

- Nearly 8,000 linear feet of archival materials and rare books

- Collections document Atlanta University Center institutions and the African American experience primarily in Atlanta and Southern United States

- Digital collections include Morehouse College Martin Luther King Jr. and Tupac Amaru Shakur Collections, photographs, audio and moving image materials 


\section{Digital Services Department}

- Digitization Services Patron requests

Projects

Exhibits

- Repository Management

- Archival Systems Support ArchivesSpace XTF

- Library ILS

- Digital Preservation

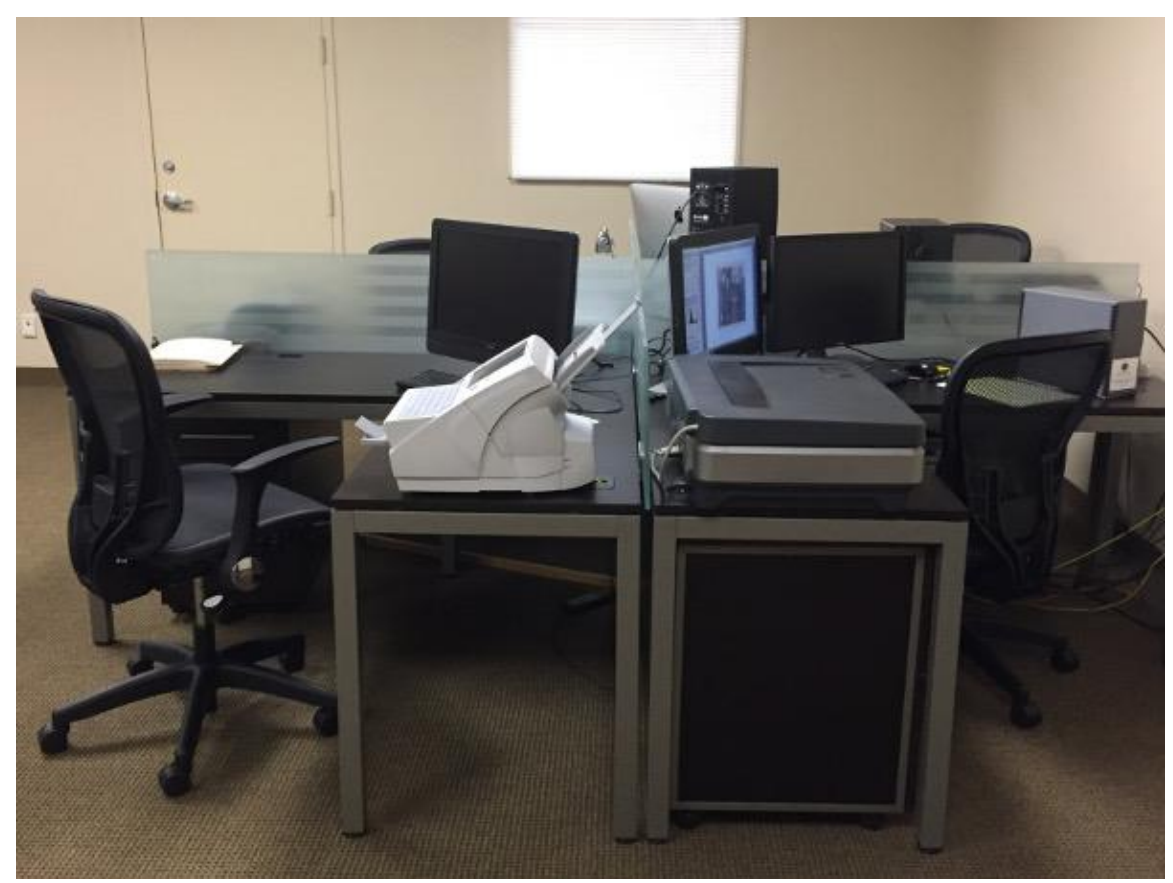




\section{Digital Initiatives and Archival Collections}

Archival

Systems

Support

Digital

Humanities

Projects

Mass Digitization

Projects
Digital Preservation Planning

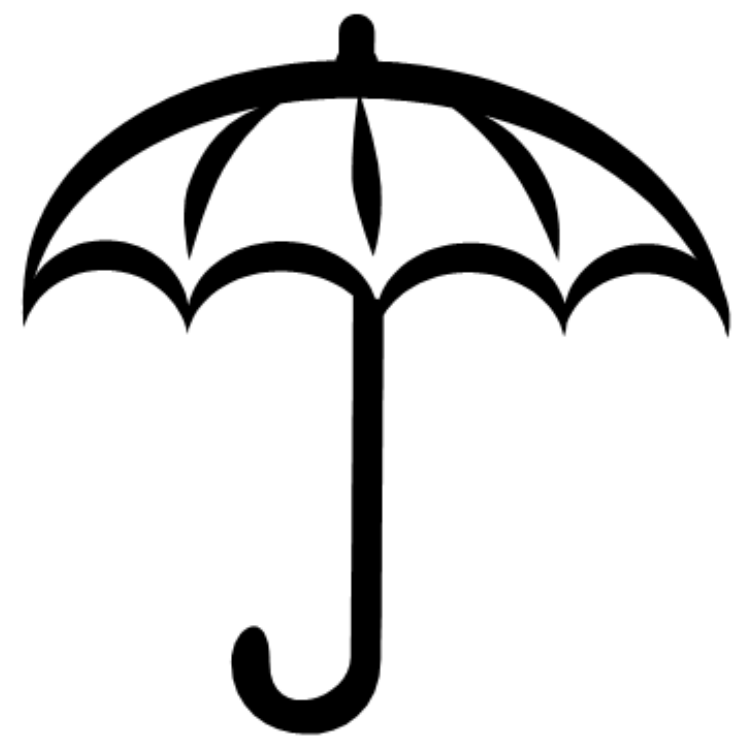

Digital Exhibits
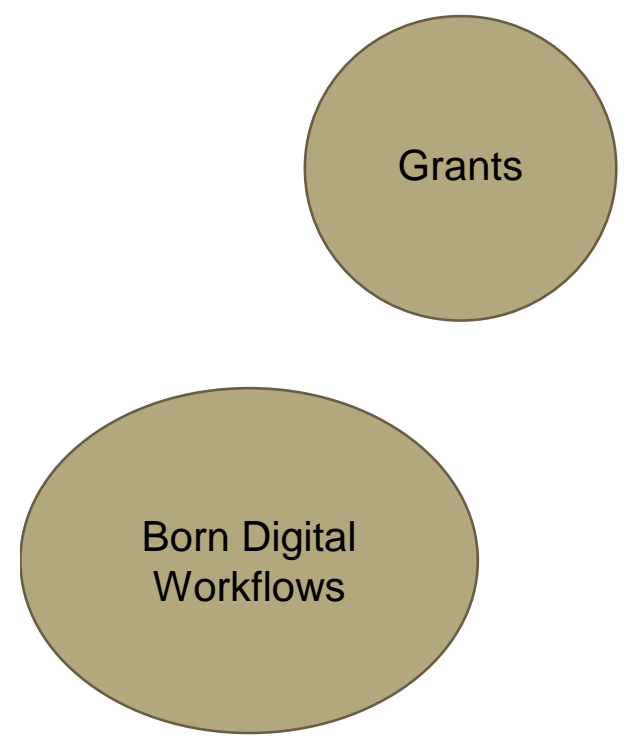

Atlanta University Center Robert W. Woodruff Library 


\section{Morehouse College Martin Luther King Jr. Collection - limited accessibility}

- Approximately 13,000 items (over 50,000 pages)

- Over 1100 books

- Fifteen series, including:

Writings by MLK

Writings by others

Correspondence

Educational Materials

Southern Christian Leadership Conference Montgomery Improvement Association

Dexter Avenue Baptist Church

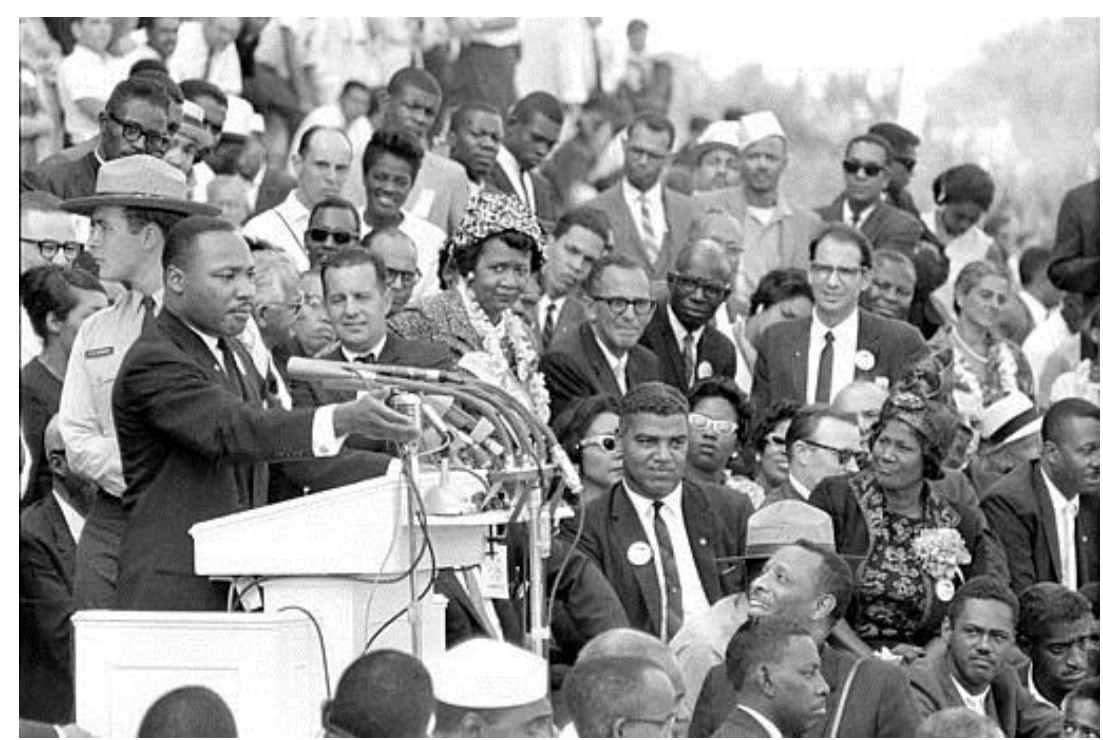

Ebenezer Baptist Church

March on Washington, 1963, Courtesy of Associated Press

Photographs 


\section{Tupac Amaru Shakur Collection - limited accessibility}

- 11.5 linear feet (28 boxes)

- Nine series:

Writings by Tupac Amaru Shakur Writings by Others

Correspondence

Media and Publicity

Clinton Correctional Facility Records Euphanasia Organizational Records Legal Records Photographs Memorabilia

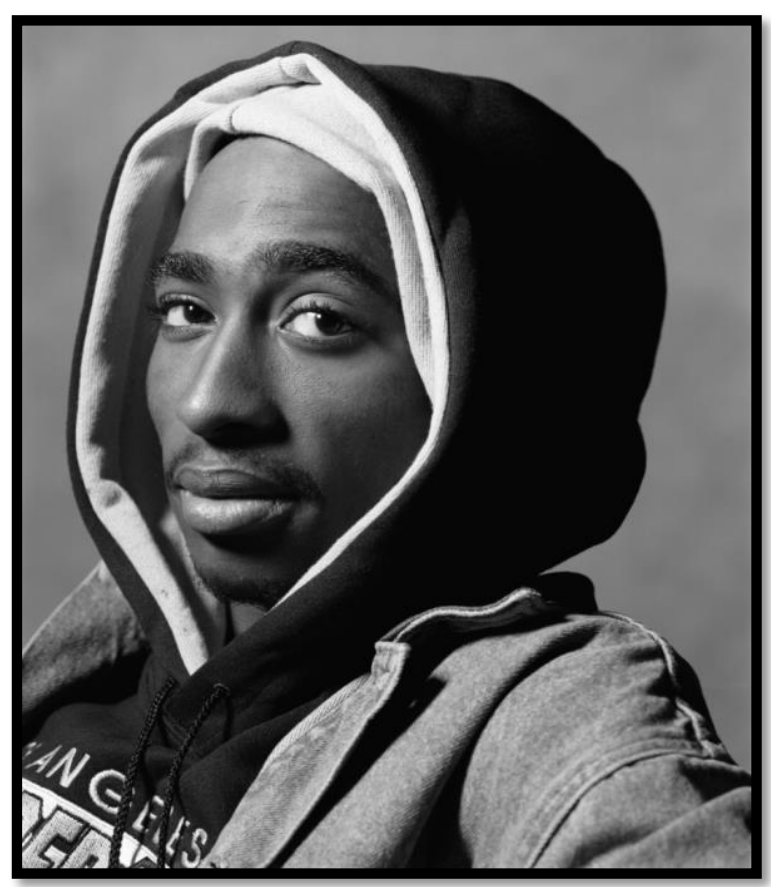

Promotional image of Tupac Shakur, undated.

- Digital AND physical collection 


\section{Finding Aids - external and internal}

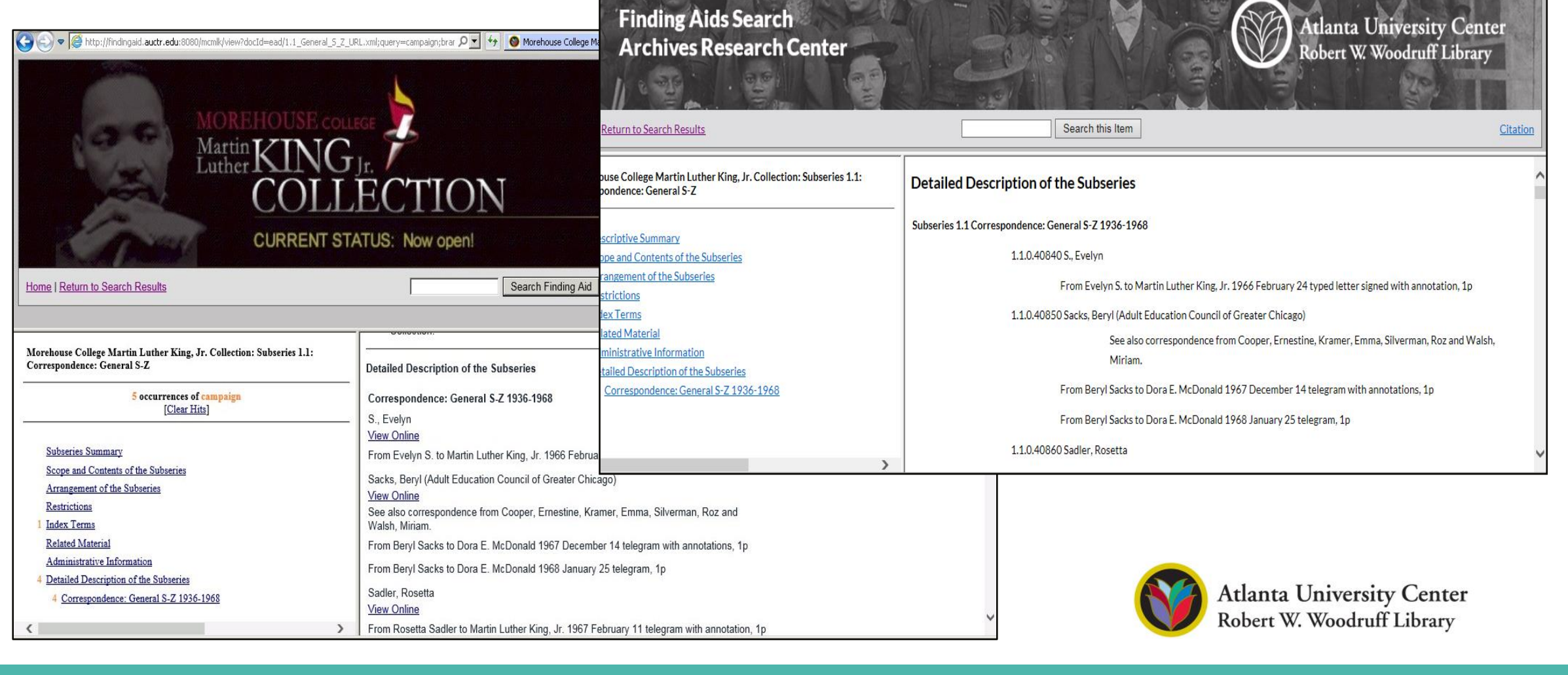




\section{Digital Collections}

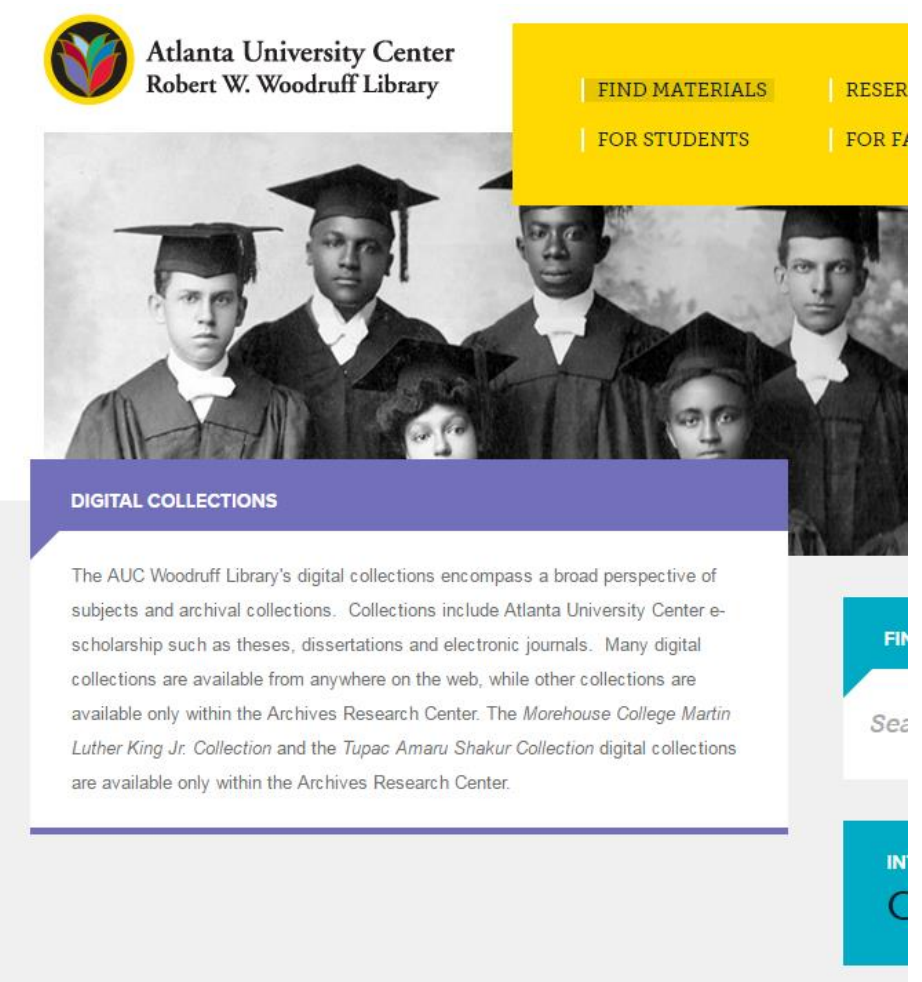

- HBCU Library Alliance, http://hbcudigitallibrary.auctr.edu/cdm/

- Digital Commons @ AUC Woodruff Library, e-Scholarship IR, http://digitalcommons.auctr.edu/

- Digital Exhibits, http://digitalexhibits.auctr.edu/

available only within the Archives Research Center. The Morehouse College Mart

Seä 


\section{HBCU Library Alliance Digital Collection}

\section{http://hbcudigitallibrary.auctr.edu/cdm/}

- Collaborative digital initiative funded by The Andrew W. Mellon Foundation starting in 2005

- Subject focus: founding documents

- Role of HBCUs in the history of African American higher education

- Early 1800s - present

- Photographs, publications, letters, programs, memorabilia

- Platform: CONTENTdm; harvested by Digital

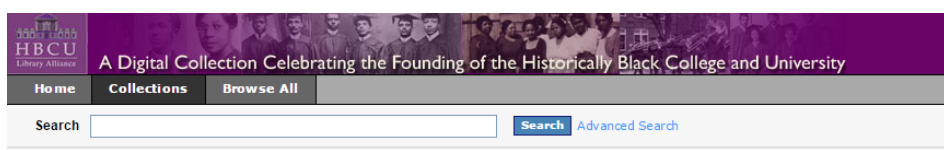

HBCU Library Alliance Digital Collection

All Collections
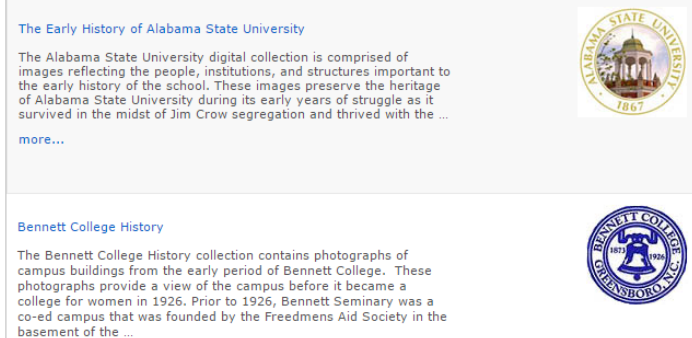

A Digital Collection Celet
Founding of the Historica

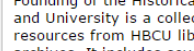

canned pages and rep

libraries first collaborath
a historic collection digit a historic collection dig
collections are contribut libraries of the Historical
and University Library A

The collection includes $p$
university corresponden

university corresponden
images of campus buildiu
tetters, memorabilia, an

These images present $H$
social, and political insti

Bowie State University - Historical Images Collection Library Georgia 


\section{Digital Commons@AUC Woodruff Library}

- http://digitalcommons.auctr.edu/

- Hosted open access institutional repository software from bepress

- Over 3,700 digital items accessible

- Total downloads: 396,695

- Downloads this year: 179,574

- Metadata harvested by DLG, DPLA, GKR, Global ETD Search

The Archives Research Center (ARC) has many individual, familial, and organizational collections. The archives are located on the upper level of the Library in the Virginia Lacy Jones Exhibition Hall. Visitiors are encouraged to make appointments 24 business hours in advance to ensure materials will be accessible, and stafi is available to assist

Digitized collections of the

please visit our website.

Follow

Browse the Archives Research Center Collections:

Asa G. Hilliard. III Papers, Audio-Visual Materials Series

Soreading the Word Project

- Anna E. Hall Collection, Photographs

- Interdenominational Theological Center Photograph Collection

- J Howard Dell Collection. Photographs

Vivan Wilson Henderson Papers Audio-Visual Materials

- Vivian Wilson Henderson Papers, Audio-Visual Recordinge

- Vivian Wilson Henderson Papers. Photographs 


\section{Digital Exhibits}

- Seeking to Tell A Story: Political Action from Slavery to Civil Rights focus on Atlanta Student Movement OMEKA

\section{http://digitalexhibits.auctr.edu/}

- Finding A Way: The Black Family's Struggle for an Education

HTML web exhibit

Needs updating http://findingaway.auctr.edu/

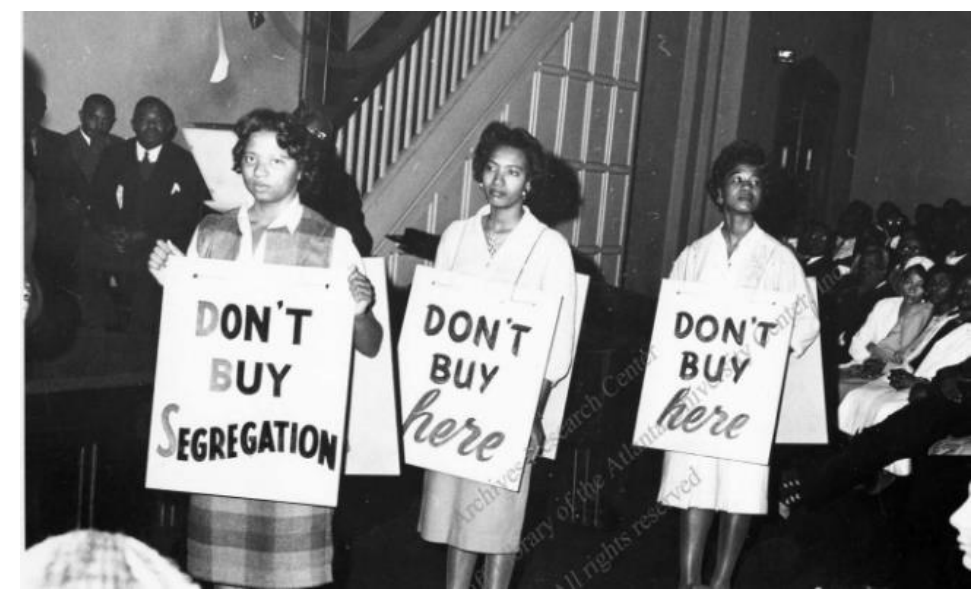

"Don't Buy Here," 1960, Mary Ann Smith Wilson Ruby Doris Smith Robinson Collection on Student Activism, featured in Seeking to Tell a Story: Political Action from Slavery to Civil Rights exhibit,

http://digitalexhibits. auctr.edu/items/show/169. 


\section{Grants - broad accessibility}

\section{HBCU Photograph Preservation Project, Round III}

- Mellon funding via LYRASIS

- Conservation treatment of Class Composites

- Digitized audio, video and photographs identified as priorities in prior grants

- Mentoring and training interns

- Career Roundtable Event

- Staff training and consulting

- Outreach to faculty

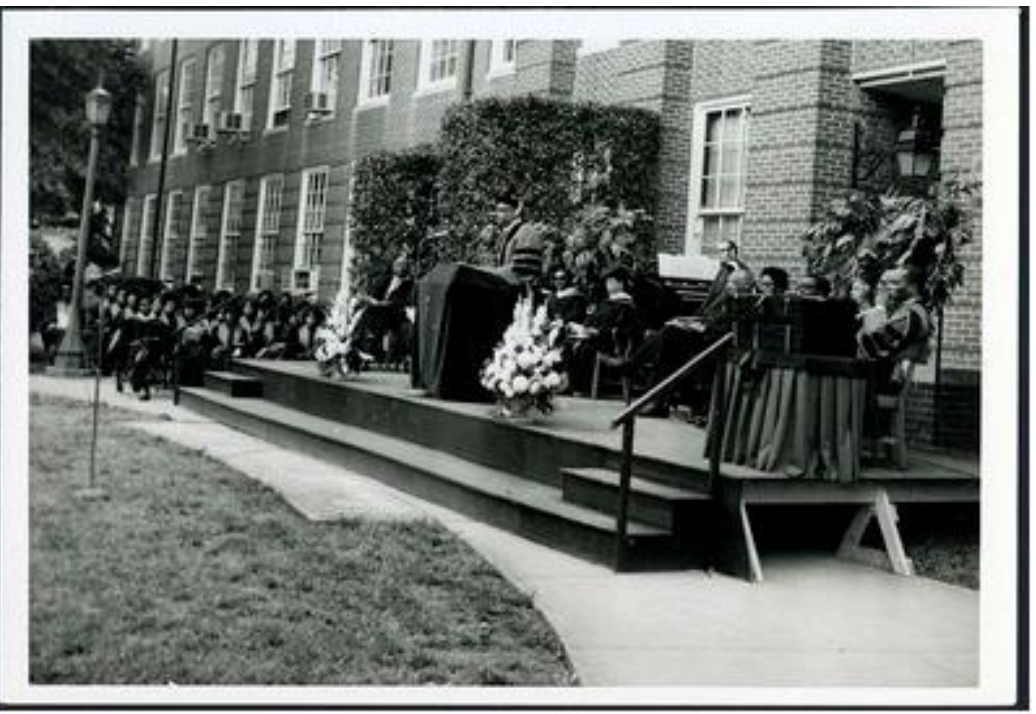

Clark College Commencement, ca 1970, Vivian Wilson Henderson Papers, Atlanta University Center Robert W. Woodruff Library. 


\section{Grants - broad accessibility}

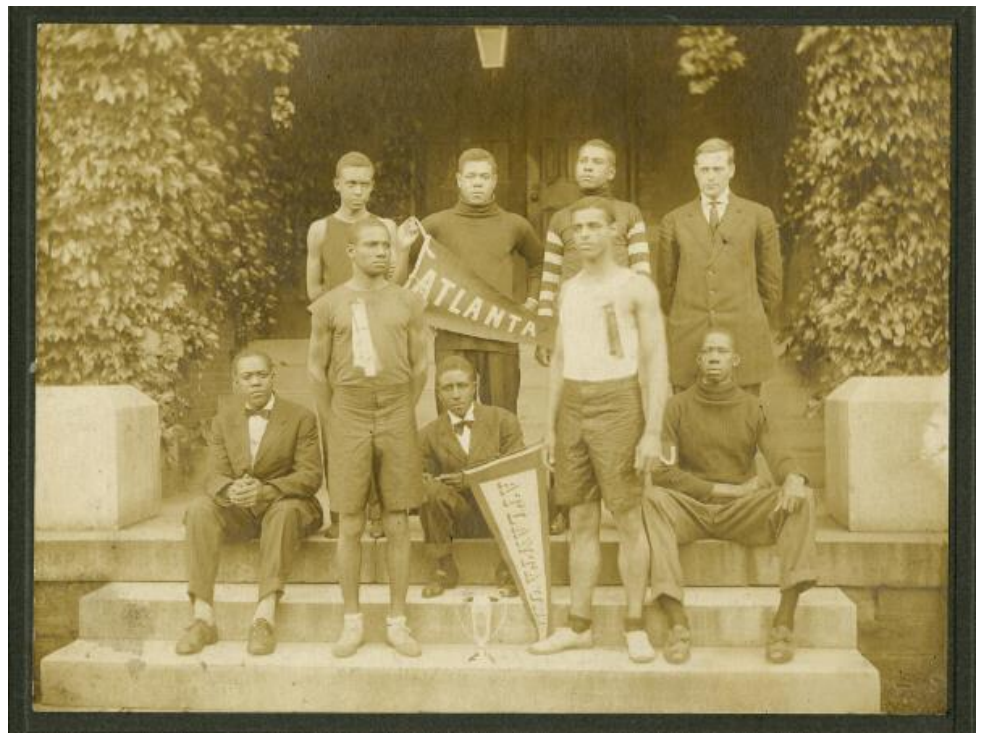

\section{Knight Foundation \& Digital Library of Georgia}

- Collaboration with Digital Library of Georgia

- Digitization of 350 pre-1925 photographs from Atlanta University Photographs and Clark College Photographs

- Images posted on DLG portal, http://dlg.galileo.usg.edu/Institutions/auu.html

- Metadata harvested by DPLA

Atlanta University Track Team, 1903, Atlanta University Photographs, Atlanta University Center Robert W. Woodruff Library, Presented in the Digital Library of Georgia. 


\section{Grants - broad accessibility}

\section{Spreading the Word: Expanding}

Access to African American Religious Archival Collections

- NEH Preservation and Access, July 2015June 2018

- $\quad$ Fully process 14 archival collections

- $\quad$ Digitize and provide access to 1,100 audio and video assets, and 2,100 photographs

- Incorporate resources into training and outreach

- Project blog: https://aucwoodruffarchives.wordpress. $\mathrm{com} /$

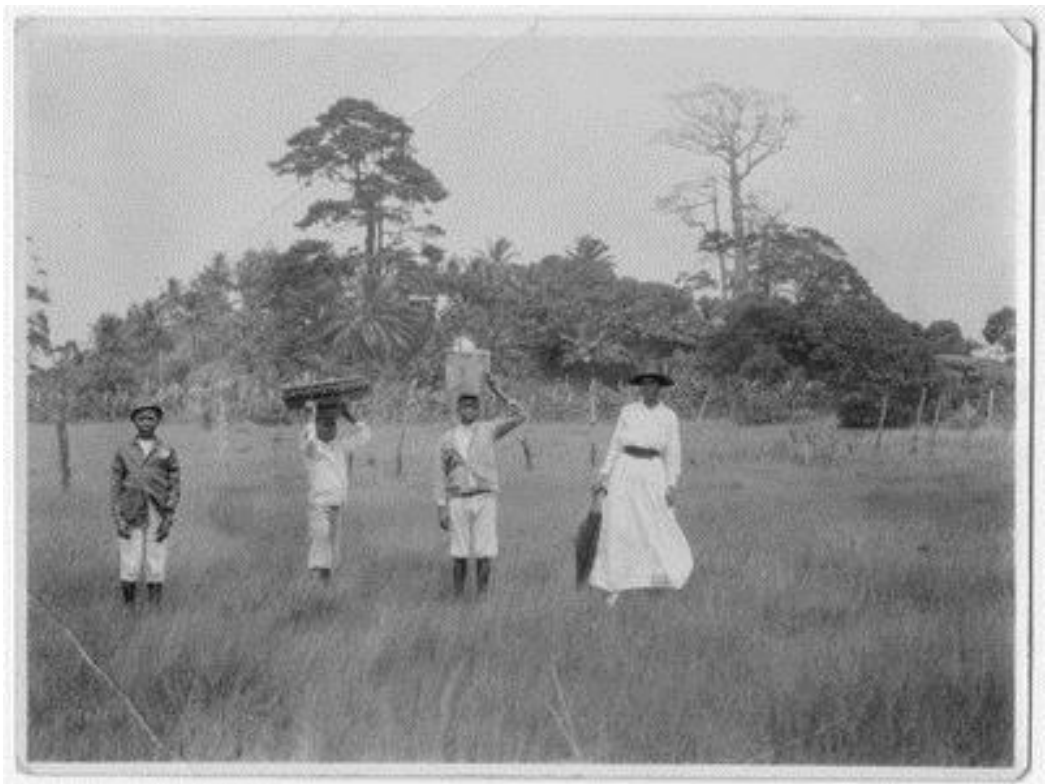

Anna E. Hall, ca. 1925, Anna E. Hall Collection, Photographs, Image 16, Atlanta University Center Robert W. Woodruff Library. 


\section{Outreach: Course Integration}

10 Greatest Men of Century, ca. 1960-1965, Morehouse College Martin Luther King Jr. Collection, Atlanta University Center Robert W. Woodruff Library.

[Image Extracted]

- Partner with Director of Office of Morehouse College Martin Luther King Jr. Collection

- Interdisciplinary Approaches

Humanities:

- Primary Document Analysis

- King's research on philosophers

STEM:

- Calculation of March on Washington distance and mileage

- Challenges with assignments using technology 


\section{Outreach: Faculty and Student Engagement}

D "Session 16: "Tupac An 4 $x$ Ions.auctr.edu/tascc/25/

LINKS

Robert W. Woodruf Library

AUTHOR CORNER

Author FAQ
Session 16: "Tupac Amaru Shakur in the

Archives and the Classroom: Outcomes from a

Gender, Race and Religion in Hip Hop Seminary

Course"

Shanesha R.F. Brooks-Tatum

Christopher Reeves

Jerri'Me Wright

Document Type

Video

Publication Date

9-29-2012

Abstract

A panel presentation "Tupac Amaru Shakur in the Archives and the Classroom:

Shanesha R F. Gronder, Race and Religion in Hip Hop Seminary Course by Dr.

Wright.

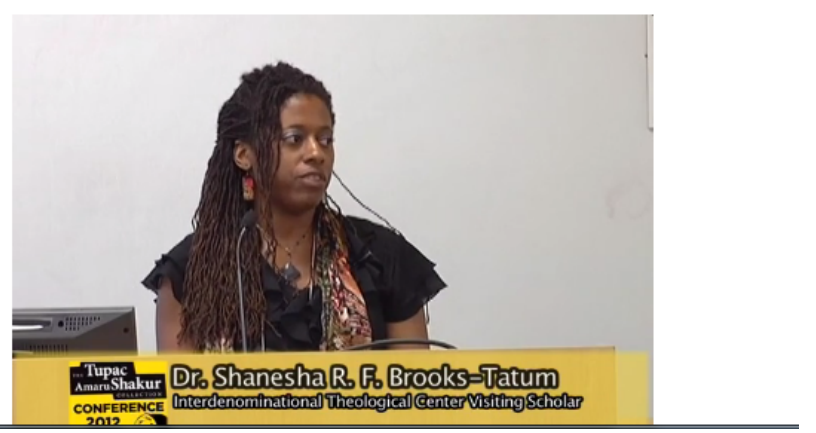

fruin
Tupac Amaru Shakur Collection Conference Videos, Sept. 2012, Atlanta University Center Robert W. Woodruff Library.

- Partnered with Innovative Learning Institutes and Faculty

- Faculty served on conference planning committee

- Other outreach activities:

- Block Party

- Exhibits

- Challenges with remote instruction and presentations 


\section{Remote Use of Openly Accessible Digital Collections \\ ASCAC Ghana Conference-Dr. Jacob}

Carruthers \& Saba Greg Kimathi Carr for Dr. John Henrik Clarke

\section{ASCAC Ghana Conference}

Greg Kimathi Carr

\section{Jacob Carruthers Dr.}

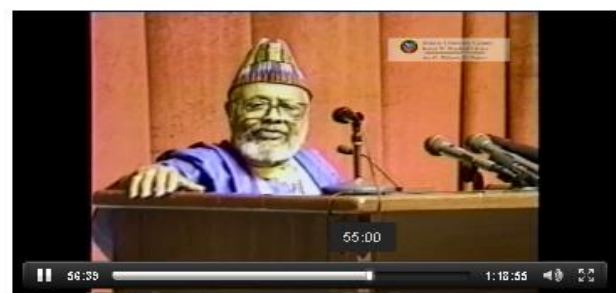

File Name
auc.002. b224110. 19970000. vido003

Document Type

Date Information
$1920-07-05$

Playing Time

Abstract

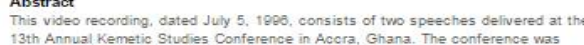

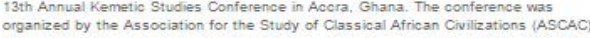

The first presentation is a paper by African Studies professsor John Henrik Clarke.

Howard University. Dr. Clarke's paper focuses on the history of Ghanaian resistance
to outside domination and Ghanais Therature of liberation. "The second presentation,

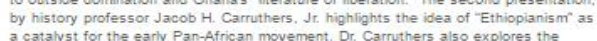

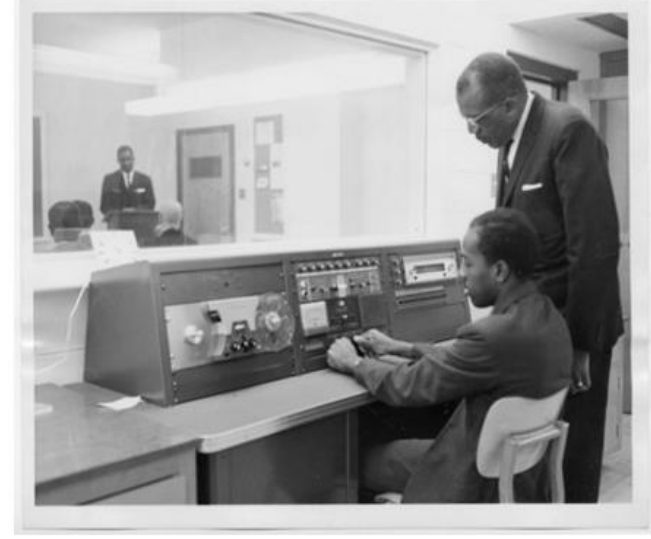

Collection

Interdenominational Theological Center Photographs collection

Description

Class in homiletics and speech training. Written on verso: Wm. Graves, Rev. M. L.

Darnell.

Date Information

1962

Format

black-and-white photographs
- Grant Outcomes

- Distance Learning Religion and Philosophy

- Thematic Course Integration

Pan Africanism

Civil Rights

Black Arts/Aesthetics

- E-Learning Technologies

Social Media

Video from Asa G. Hilliard, III Papers, 1996, Atlanta University Center Robert W. Woodruff Library.

Photograph from Interdenominational Theological Center Photographs, Atlanta University Center Robert W. Woodruff Library. 


\section{Digital Collections Quandary}

\section{Limited Accessibility Issues}

- Social Media

- $\quad$ Course Management Systems

- Distance Learning

- Remote Access

- Permissions

- Collaborative Initiatives

\section{Broad Accessibility Issues}

- $\quad$ Selective Digitization

- Copyright Restrictions

- Loss of Content Control 


\section{THANK YOU! Questions?}

Andrea Jackson, Head of Archives Research Center ajackson@auctroedur.

Christine Wiseman, Head of Digital Services Department cwiseman@auctir.edu

\section{www.auctr.edu}

